Acta vet. scand. $1971,12,467-478$.

From the Department of Food Hygiene, Royal Veterinary College, Stockholm, Sweden.

\title{
BACTERIOLOGY OF WASHED AND UNWASHED EGGS
}

\section{BACTERIAL COUNTS OF EGG CONTENTS AFTER STORAGE ${ }^{\star}$}

\author{
By \\ Kurt Östlund
}

It has been documented that dirty eggs are more prone to spoilage than are clean eggs (Rosser 1942, Lorenz \& Starr 1952, Lorenz et al. 1952 a, Winter et al. 1952).

However, in producing eggs, it is not possible to avoid contamination of at least a small percentage of the shell eggs by hen feces. In order to make such eggs less prone to spoilage and more attractive to the consumers, producers of eggs have always tried to employ washing methods for the cleaning of dirty eggs.

Several investigations have been made on the microbiological conditions in egg spoilage and on the bacteriological effects of a washing procedure but the results have of ten been confusing and contradictory.

Rosser and Board et al. (1964) found that the number of microorganisms on the surface of unwashed eggs was fairly constant during storage under various conditions. Forsythe et al. (1953) found this to be the case for washed as well as for unwashed eggs. Rievel (1939) showed that fluorescent bacteria easily penetrate the eggshell and that this penetration is dependent on the infective mass and greatly favoured by any form of humidity. Haines \& Moran (1940) showed that microorganisms may be drawn through the shell by simple suction if an egg is

* The investigation was supported by a grant from the Royal Veterinary Board, Sweden. 
immersed in a fluid containing bacteria and the temperature of the egg is higher than that of the fluid. The authors drew attention to the significance of this phenomenon in the washing of eggs.

Also Lorenz et al. (1952 a) found that the probability of infection increased with increasing positive temperature differential between the egg and a suspension of bacteria, in which the egg was immersed. These observations are in agreement with the findings by Wright (1948), Miller et al. (1950) and Lorenz \& Starr, that washing of eggs in cold water produces more spoilage than washing in warm water. Davidson et al. (1950) reported that the incidence of souring in storage increased materially by washing the eggs under uncontrolled conditions in farms prior to oil treatment and storage.

In contrast to most other investigators, Williams \& Goble (1950) could not find any difference in the percentage of inedible eggs between washed and unwashed eggs after storage, even if the washing was performed by hand in cold water.

Lorenz et al. (1952 b) found that eggs that had been handwashed after brief soaking in alkaline detergent survived storage satisfactorily, but that presoaking of heavy dirties prior to machine washing resulted in striking increases in spoilage. Brown et al. (1966) found that the washing of eggs in clean, warm water had no influence on the storage properties, but that contamination of the washing water by hen feces resulted in increasing spoilage during storage. Trussel (1955) investigated the degree of spoilage in unwashed eggs and in eggs washed at the producers' farms and found a considerably higher spoilage in the washed eggs. The author assumed that the method of washing was of great significance and that washing under strictly controlled conditions would give a different result. March (1969) determined the surface contamination of eggs before and after a washing procedure not described by the author, and found that a higher portion of the eggs was heavily contaminated after washing than before.

Starr et al. (1952) washed eggs at $50-60^{\circ} \mathrm{C}$ after holding the eggs for $24 \mathrm{hrs}$. before washing and obtained no greater spoilage in these eggs than was obtained in unwashed eggs from the same source. However, the authors noted a higher frequency of spoilage in eggs washed on the ranch under conditions, essentially similar to those which gave satisfactory results in the laboratory. For- 
sythe et al. washed eggs under controlled conditions in water (with additives) at $43^{\circ} \mathrm{C}$, resulting in a decrease of $80-90 \%$ of the total organisms on the shell surface. This decrease was permanent when the eggs were held in storage. The washed eggs also had fewer microorganisms on the inside after storage than unwashed eggs. The authors concluded that the cleaning of all eggs, clean and dirty, would be desirable if properly carried out. Pino (1950) concluded that "eggs which have been collected in wire baskets, submerged momentarily in a $1 \%$ detergent solution at a temperature of $140^{\circ} \mathrm{F}\left(60^{\circ} \mathrm{C}\right)$, rinsed with a forceful spray of tap water at $140^{\circ} \mathrm{F}$, and air dried with the aid of a fan maintain an internal quality equal to that of untreated eggs kept under the same storage conditions".

It may be concluded from the literature in this field that the way of washing eggs is of great significance for the resulting storage properties of the product. There is no doubt that hand washing under badly controlled conditions has an undesirable influence on the storage properties of the eggs. Nevertheless it is known that in Sweden, a considerable percentage of the eggs for consumption is sold on the retail market after washing under uncontrolled conditions. This washing is performed by the producers and seems mainly to be due to the fact that the producers receive reduced rates for dirty eggs. Under such circumstances it would be desirable that all eggs, clean and dirty, could be subjected to washing under controlled conditions at the receiving stations, provided that the washing procedure in no way harms the storage properties of the eggs. Such an arrangement would result in a higher average storage quality of the shell eggs, since no producer - if the economic sanctions towards producers of dirty eggs are reduced or eliminated - would be tempted to wash eggs before delivery to the grading stations.

The present investigation was performed in order to study the influence of industrial large-scale washing of uncracked eggs under strictly controlled conditions on the bacteriological quality of eggs for market. The investigation was divided into two parts. This part deals with the quality of washed and unwashed eggs by comparing the microbiological counts of the egg contents after storage at different temperatures. The possibility for Salmonella bacteria to penetrate the shells of washed and unwashed eggs under different conditions is presented in a separate study (Östlund 1971). 


\section{MATERIALS AND METHODS}

General performance of the experiment. Equal numbers of washed and unwashed eggs were kept for eight weeks in cold storage, resembling the normal storage and handling conditions for market eggs. At the end of the storage period the bacterial counts of the contents of each egg were determined and the results for washed and unwashed eggs were statistically compared. Equal numbers of washed and unwashed eggs were also stored for 12 days at elevated temperature $\left(30^{\circ} \mathrm{C}\right)$. Bacteriological investigation and statistical comparison were made at the end of the storage period as described for cold stored eggs.

Eggs. All eggs used in this study were from a single strain of single-comb White Leghorns from one farm. The frequency of visibly dirty eggs from this farm was fairly high, or about $20 \%$. The eggs were in no case older than four days when the washing was performed.

Washing of eggs. Eggs for the investigation were selected at random on delivery to the grading station and every second egg was submitted to machine washing.

The washing was performed using a commercially available egg washer (Kuhl HVEVCS 35-6, Kuhl Poultry Equipment Co., Flemington, N.J., USA), completed with an apparatus for automatic dosage of detergent (Solu-Matic 24, Economics Laboratories, Inc., St. Paul, Minnesota, USA) and a hot air dryer equipped with fans.

The eggs passed the machine with the pointed end down on a conveyor belt. The washing procedure consisted of sprinkling under pressure with a $43^{\circ} \mathrm{C}$ water solution of detergent, and rinsing in $47^{\circ} \mathrm{C}$ tap water, immediately followed by drying in a stream of hot air $\left(60-65^{\circ} \mathrm{C}\right)$. The time needed for an egg to pass the machine, i.e. from entering the machine and until it was delivered in the dry state, was about $2 \mathrm{~min}$. $30 \mathrm{sec}$. The detergent used was Kleen-Shel 440 (AB Soilax, Bandhagen, Sweden) in a concentration of $0.1 \%$. According to the manufacturer, this detergent also contains an organic chlorine sanitizer and a defoaming agent.

Storage conditions. All eggs were placed with the pointed end down on commercially sterile egg trays. One hundred washed and 100 unwashed eggs were stored for 56 days at $4^{\circ} \mathrm{C}$ and a relative humidity of $85-88 \%$. One hundred washed and 100 
unwashed eggs were stored for 12 days at $30^{\circ} \mathrm{C}$ and a relative humidity of $55-60 \%$.

Bacteriological investigation. At the end of the storage period, the eggs were one by one totally immersed in $70 \%$ ethanol for five min. and then flamed. The shell over the air chamber was peeled off under sterile conditions by means of forceps. The egg contents were then poured down into a test tube $(155 \times 32 \mathrm{~mm})$ and homogenized using a high-speed homogenizer (Ultra-Turrax TP 18/2, AB Kistner, Stockholm, Sweden). From the homogenate serial decimal dilutions with physiological saline solution were made. One $\mathrm{ml}$ of each of the dilutions was inoculated in different types of agar plates.

The total count of bacteria was determined by cultivation at $30^{\circ} \mathrm{C}$ using meat-extract peptone agar, containing $5 \%$ horse serum. All colonies visible to the naked eye were counted after 72 hrs.' incubation. The number of hemolytic bacteria was determined by cultivation using meat-extract peptone agar, containing $5 \%$ defibrinated horse blood. Hemolyses, visible to the naked eye, were counted after $48 \mathrm{hrs}$.' incubation at $37^{\circ} \mathrm{C}$. The number of coli-aerogenes was determined with the aid of violet-red-bile agar (VRB) at $37^{\circ} \mathrm{C}$. All red colonies, surrounded by a red precipitation zone in the substrate were counted after 24 hrs.' incubation.

Mathematical treatment of bacterial counts. All bacterial counts were expressed as the logarithmic value of the number of bacteria per $g$ egg contents. Also in the statistical treatment the logarithmic values were used, which seems most logical with regard to the way of bacterial multiplication by division. The bacteriological methods used did not permit detection of bacterial counts less than 10 microorganisms per $\mathrm{g}$ of the sample. Thus, the number of bacteria in certain samples had to be expressed as "less than 10" per g of egg contents. The logarithmic value of the total number of bacteria in such samples was in certain cases set equal to zero. This approximation was made when comparing two groups of eggs, containing a few such samples and when the number of such samples in the two groups to be compared was of the same order. Under such circumstances and considering the nature of microbial division, the error produced by this approximation will be negligible. 


\section{RESULTS AND DISCUSSION}

After storage for eight weeks at $4^{\circ} \mathrm{C}$ practically no difference could be seen between unwashed and washed eggs as regards the total number of bacteria (Table 1). The logarithmic values of total counts were $2.07 \pm 1.47$ and $2.08 \pm 1.51$, respectively (mean $\pm \mathrm{s}$ ), and the corresponding $\mathrm{t}$-value was $0.047(\mathrm{P}>0.99)$. The median value was somewhat lower in washed eggs (1.95)

T a ble 1. Statistical comparison between log. total number of bacteria in the contents of unwashed and machine washed eggs after storage at $4^{\circ} \mathrm{C}$ for eight weeks and after storage at $30^{\circ} \mathrm{C}$ for 12 days.

\begin{tabular}{|c|c|c|c|c|}
\hline & & \multicolumn{2}{|c|}{$\begin{array}{l}\text { Log. total number } \\
\text { of bacteria }\end{array}$} & \multirow{2}{*}{$\begin{array}{l}\text { t-test } \\
\text { washed- } \\
\text { unwashed } \\
\text { eggs }\end{array}$} \\
\hline & & $\begin{array}{l}\text { unwashed } \\
\text { eggs }\end{array}$ & $\begin{array}{l}\text { washed } \\
\text { eggs }\end{array}$ & \\
\hline \multirow{3}{*}{$\begin{array}{l}\text { Eggs stored } \\
\text { at } 4^{\circ} \mathrm{C} \text { for } \\
8 \text { weeks }\end{array}$} & mean $\pm s$ & $2.07 \pm 1.47$ & $2.08 \pm 1.51$ & \multirow{3}{*}{$\begin{array}{l}t=0.047 \\
P>0.99\end{array}$} \\
\hline & median value & 2.42 & 1.95 & \\
\hline & $n$ & 93 & 99 & \\
\hline \multirow{3}{*}{$\begin{array}{l}\text { Eggs stored } \\
\text { at } 30^{\circ} \mathrm{C} \text { for } \\
12 \text { days }\end{array}$} & $\int$ mean $\pm s$ & $1.40 \pm 1.34$ & $1.62 \pm 1.47$ & \multirow{3}{*}{$\begin{array}{l}t=1.177 \\
0.2<P<0.3\end{array}$} \\
\hline & median value & 1.30 & 1.48 & \\
\hline & n & 111 & 110 & \\
\hline
\end{tabular}

than in unwashed (2.42), which is in agreement with the fact that the mean value for washed eggs seems to be slightly displaced by a single, high bacterial count value (log. value $>5.0$, Fig. 1 ). As seen from Fig. 1, no considerable systematic differences occurred between the two groups of eggs, concerning the distribution pattern for the eggs between groups with increasing bacterial counts.

In the cold stored eggs, hemolytic bacteria could be detected in $35.2 \%$ of the unwashed eggs and in $33.0 \%$ of the washed eggs. The logarithmic bacterial values for these eggs were $2.43 \pm 0.64$ and $2.47 \pm 0.91$, respectively, and the corresponding t-value was $0.197(0.8<\mathrm{P}<0.9)$, showing that no differences existed between the groups. Coli-aerogenes bacteria could not be detected in any washed or unwashed eggs, stored at $4^{\circ} \mathrm{C}$.

In the eggs stored at $30^{\circ} \mathrm{C}$ a certain difference between the total numbers of bacteria in unwashed and washed eggs could be 
seen. The median value (logarithmic) was for unwashed eggs 1.30 and for washed eggs 1.48 (Table 1 ). The mean values $\pm s$ were $1.40 \pm 1.34$ and $1.62 \pm 1.47$, respectively. However, this difference was not significant $(\mathrm{t}=1.177,0.2<\mathrm{P}<0.3)$. The minute differences between unwashed and washed eggs in respect of distribution between classes with increasing bacterial counts are illustrated in Fig. 2.

The values for hemolytic bacteria also differed slightly between unwashed and washed eggs, the difference not being sig-

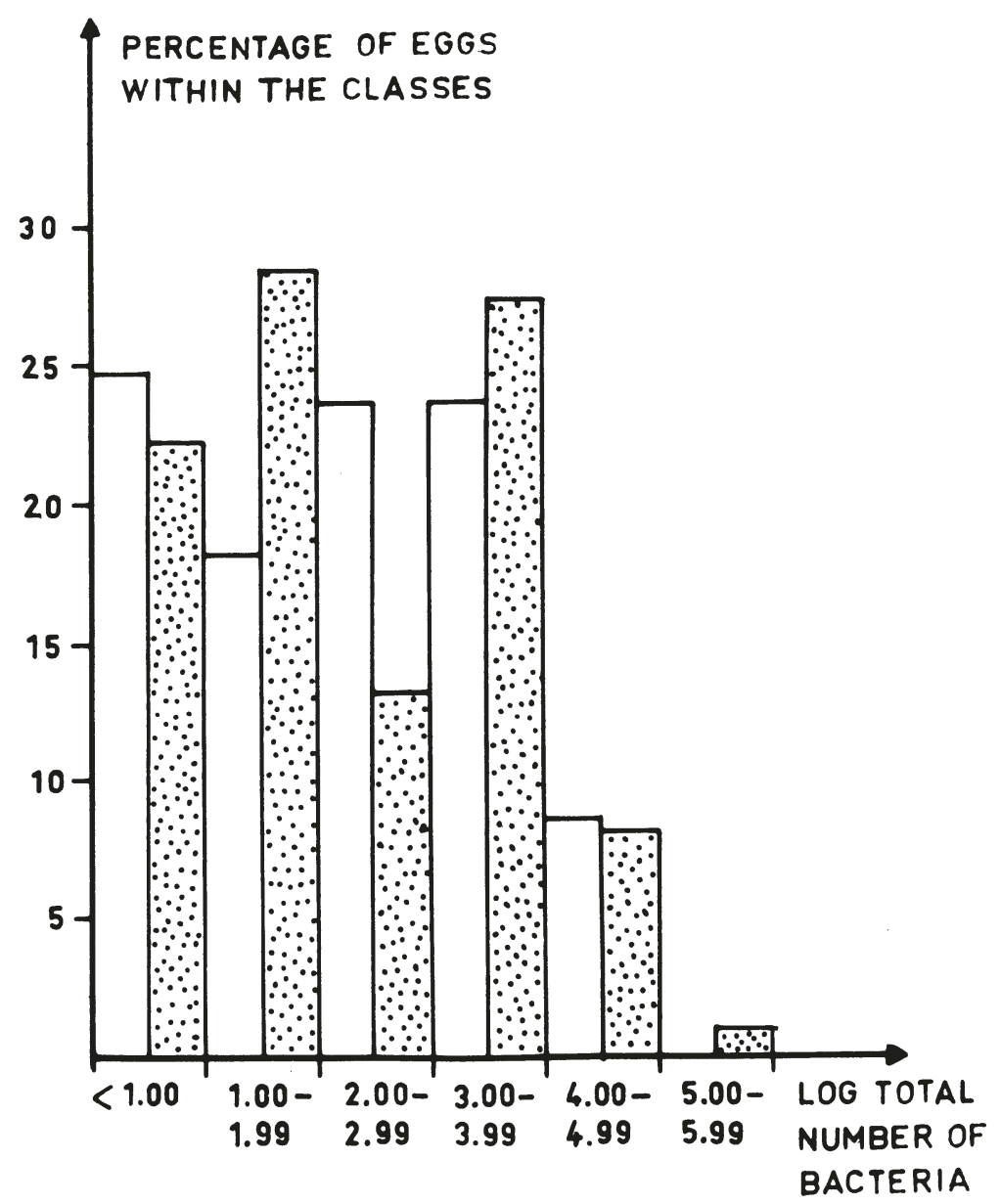

F i g u r e 1. Distribution of unwashed and washed eggs according to their total bacterial count after storage at $4^{\circ} \mathrm{C}$ for eight weeks. White columns represent unwashed and dotted columns washed eggs. 
nificant (Table 2). Hemolytic bacteria were found in $19.6 \%$ of the unwashed and in $23.9 \%$ of the washed eggs. The logarithmic numbers of bacteria in these eggs were $2.10 \pm 0.71$ and $2.46 \pm 1.08$, respectively, corresponding to a $\mathrm{t}$-value of $1.327(0.1<\mathrm{P}<0.2)$. No coli-aerogenes bacteria were detected in eggs stored at $30^{\circ} \mathrm{C}$.

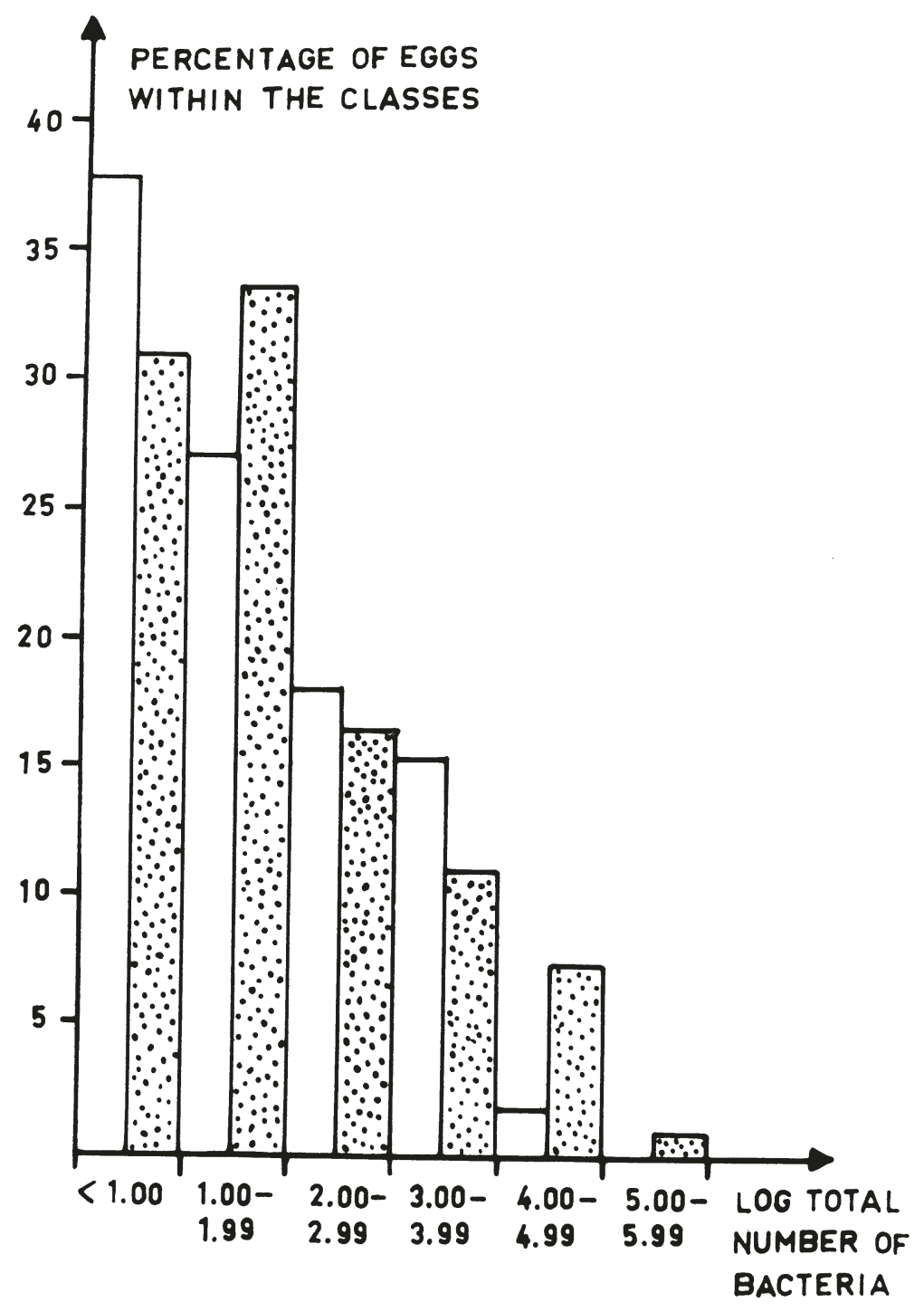

F i g u r e 2. Distribution of unwashed and washed eggs according to their total bacterial count after storage at $30^{\circ} \mathrm{C}$ for 12 days. White columns represent unwashed and dotted columns washed eggs. 
Bacteriology of washed and unwashed eggs. I

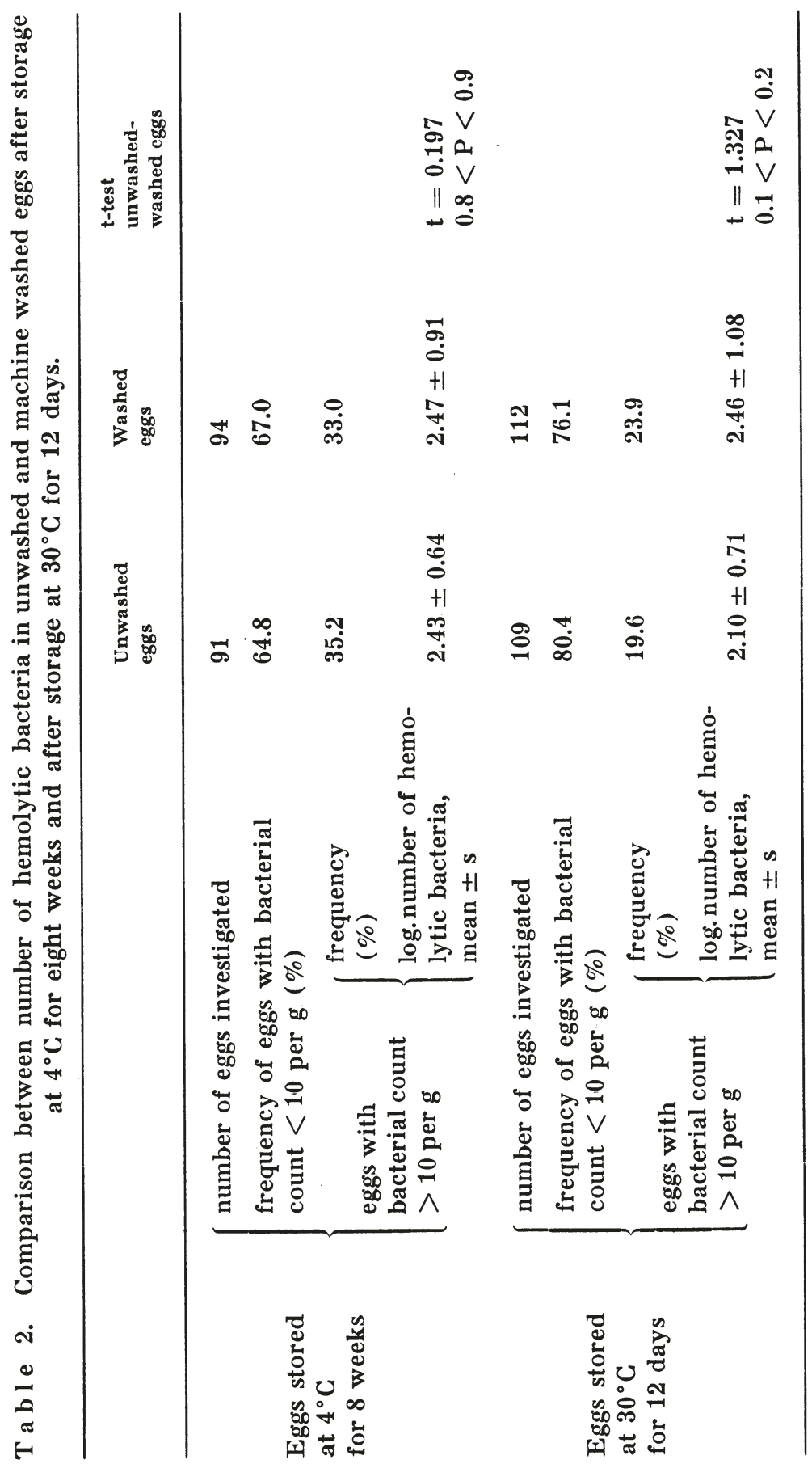


It is a well-known fact that the washing of eggs under unfavourable conditions results in striking increases in losses during storage. From these findings the conclusion has sometimes been made that all egg washing has an undesirable influence on the storage properties. In the present investigation, however, no significant differences could be seen in bacterial counts between unwashed eggs and eggs washed under strictly controlled conditions. Thus it may be immediately concluded that the way of washing has a definite influence on the storage properties of eggs. Furthermore it may be concluded that washing of eggs performed under the conditions used in this investigation has no significant influence on the storage properties of uncracked eggs as long as no recontamination of the shell occurs after the washing and drying procedures. This conclusion is in agreement with the suggestion by Forsythe et al. (1953) that "the cleaning of all eggs, clean and dirty, would be desirable if properly carried out".

The results of the present study also suggest that the applied washing procedure causes no substantial damage to the cuticle of the egg, since Vadehra et al. (1970) have shown that removal of the cuticle from eggs resulted in spoilage at a much faster rate than in normal eggs. However, further investigations of the influence of the washing procedure on the resistance of the shell to heavy bacterial contamination are necessary.

\section{ACKNOWLEDGEMENTS}

The interest and cooperation of Dr. Sven Rydberg, Mr. Carl Scott and Mr. Göran Erixon is gratefully acknowledged.

\section{REFERENCES}

Board, R. G., J. C. Ayres, A. A. Kraft \& R. H. Forsythe: The microbiological contamination of eggshells and egg packing materials. Poult. Sci. 1964, 4.3, 584-595.

Brown, W. E., R. C. Baker \& H. B. Naylor: The microbiology of cracked eggs. Poult. Sci. 1966, 45, 284-287.

Davidson, J. A., L. E. Dawson \& C. C. Sheppard: The occurrence of sour eggs in stored eggs. Quart. Bull Mich. St. Univ. agric. exp. Sta. 1950, 32, 526-534.

Forsythe, R. H., J. C. Ayres \& J. L. Radlo: Factors affecting the microbiological populations of shell eggs. Food Technol. 1953, 7, 4956.

Haines, R. B. \& T. Moran: Porosity of, and bacterial invasion through, the shell of the hen's egg. J. Hyg. (Lond.) 1940, 40, 453-461. 
Lorenz, F. W. \& P. B. Starr: Spoilage of washed eggs. 1. Effect of sprayed versus static water under different washing temperatures. Poult. Sci. 1952, 31, 204-214.

Lorenz, F. W., P. B. Starr, M. P. Starr \& F. X. Ogasawara: The development of Pseudomonas spoilage in shell eggs. I. Penetration through the shell. Food Res. 1952 a, 17, 351-360.

Lorenz, F. W., F. X. Ogasawara \& P. B. Starr: Spoilage of washed eggs. 3. A survey of ranch practices and results. Poult. Sci. 1952 b, 31, 221-226.

March, B. E.: Bacterial infection of washed and unwashed eggs with reference to salmonellae. Appl. Microbiol. 1969, 17, 98-101.

Miller, M. W., V. Joukovsky \& A. Kraght: Experiments relating to the spoilage of washed eggs. Poult. Sci. 1950, 29, 27-33.

Pino, J. A.: Effect of washing with a hot detergent solution on keeping quality and hatchability of eggs. Poult. Sci. 1950, 29, 888-894.

Rievel, $H$. .: Die Durchlässigkeit der Eischale für die Bakterien und ihre Bedeutung für die Kühlhauslagerung. (Bacterial penetration of egg shell and its significance on the cold storage of eggs). Proc. Wld's Poult. Congr. (Cleveland) 1939, 7, 478-483.

Rosser, F. T.: Preservation of eggs. II. Surface contamination on eggshell in relation to spoilage. Canad. J. Res., E. 1942, 20 D, 291296.

Starr, P. B., F. W. Lorenz \& F. X. Ogasawara: Spoilage of washed eggs. 2. Laboratory versus ranch washing. Poult. Sci. 1952, 31, 215220.

Trussel, P. C.: Bacterial spoilage of shell eggs. I. Bacteriology. Food Technol. 1955, 9, 126-129.

Vadehra, D. V., R. C. Baker \& H. B. Naylor: Role of cuticle in spoilage of chicken eggs. J. Food Sci. 1970, 35, 5-6.

Williams, I. L. \& J. W. Goble: Egg washing studies. Nebr. Sta.63rd Ann. Rep. 1950, 126.

Winter, A. R., B. Burhart \& C. Wettling: Cleaning eggs for market. Ohio agric. exp. Sta. Res. Bull. 1952, 710.

Wright, F. B.: Egg washing machine. Amer. Egg Poult. Rev. 1948, 9, 54.

östlund, K.: Bacteriology of washed and unwashed eggs. II. Penetration of Salmonella bacteria through the eggshell. Acta vet. scand. $1971,12,479-488$.

\section{SUMMARY}

The influence of egg washing on the bacterial counts of egg contents after subsequent storage was studied. Unwashed eggs were compared to eggs subjected to industrial large-scale machine washing. The washing procedure consisted of sprinkling under pressure with a $43^{\circ} \mathrm{C}$ water solution of detergent, rinsing with $47^{\circ} \mathrm{C}$ tap water, and drying in a stream of hot air $\left(60-65^{\circ} \mathrm{C}\right)$. The eggs were stored at $4^{\circ} \mathrm{C}$ for eight weeks and at $30^{\circ} \mathrm{C}$ for 12 days. At the end of the storage periods, the total bacterial count, the number of hemolytic bacteria, and the number of coli-aerogenes in the egg contents were examined. A total of slightly more than 400 eggs were used in the investigation. 
No coli-aerogenes bacteria were detected in any washed or unwashed eggs. For eggs, stored at $4^{\circ} \mathrm{C}$, the logarithmic total bacterial counts were for washed eggs $2.07 ; 2.42$, and for washed $2.08 ; 1.9$ ๖ (mean and median values, respectively). The corresponding values for eggs stored at $30^{\circ} \mathrm{C}$ were for unwashed eggs $1.40 ; 1.30$, and for washed eggs, $1.62 ; 1.48$. These differences between unwashed and washed eggs are not significant.

Hemolytic bacteria were detected in $35.2 \%$ of unwashed and in $33.0 \%$ of washed eggs after cold storage and no significant difference was seen between the number of bacteria in these eggs (logarithmic mean values 2.43 and 2.47 , respectively). Nor was any significant difference seen between the counts of the hemolytic bacteria in eggs stored at $30^{\circ} \mathrm{C}$, where these bacteria were detected in $19.6 \%$ of unwashed and in $23.9 \%$ of washed eggs (logarithmic mean values of number of bacteria 2.10 and 2.46, respectively). The importance of obtained results is discussed from the point of view of food hygiene with references to the relevant literature.

\section{SAMMANFATTNING}

Bakteriologiska förhållanden hos tvättade och otvättade ägg.

I. Bakteriehalten hos ägg efter lagring.

Inverkan av ett äggtvättningsförfarande på äggens bakterieinnehåll efter lagring studerades. Otvättade ägg jämfördes med ägg, som maskintvättats enligt ett förfarande för industriell tvätt i stor skala. Tvättningen omfattade duschning under tryck med en $43^{\circ} \mathrm{C}$ vattendetergentlösning, sköljning i 47-gradigt vatten och torkning $\mathrm{i}$ varmluftström $\left(60-65^{\circ} \mathrm{C}\right)$. Lagring skedde vid $4^{\circ} \mathrm{C}$ i 8 veckor och vid $30^{\circ} \mathrm{C}$ i 12 dygn. Vid respektive lagringsperiods slut undersöktes ägginnehållet med avseende på totalantal bakterier, antal hämolyserande bakterier samt antalet koli-aerogenes. Undersökningen omfattade något mer än 400 ägg.

Icke i något fall kunde koli-aerogenes-bakterier påvisas i tvättade eller otvättade ägg. För ägg lagrade vid $4^{\circ} \mathrm{C}$ var log-värdet för totalantalet bakterier hos otvättade ägg 2,$07 ; 2,42$, och för tvättade ägg 2,08 ; 1,95 (medelvärde respektive medianvärde). Motsvarande värden för ägg lagrade vid $30^{\circ} \mathrm{C}$ var för otvättade ägg 1,$40 ; 1,30$, och för tvättade 1,$62 ; 1,48$. Skillnaderna mellan tvättade och otvättade ägg med avseende på dessa värden var icke signifikanta. Hämolyserande bakterier kunde påvisas i 35,2 \% av de otvättade och $33,0 \%$ av de tvättade äggen efter kyllagring och skillnaden $i$ antal bakterier hos dessa ägg var icke signifikant (logaritmiska medelvärden 2,43 respektive 2,47 ). Icke heller förelåg någon signifikant skillnad beträffande antalet hämolyserande bakterier hos ägg, lagrade vid $30^{\circ} \mathrm{C}$, där dessa bakterier kunde påvisas i $19,6 \%$ av de otvättade och i $23,9 \%$ av de tvättade äggen (logaritmiska medelvärden för antalet bakterier 2,10 respektive 2,46). Betydelsen av funna resultat diskuteras ur livsmedelshygienisk synpunkt $i$ anslutning till relevant litteratur. 